POLSKA AKADEMIA NAUK-ZAKŁAD BADANIA SSAKOW

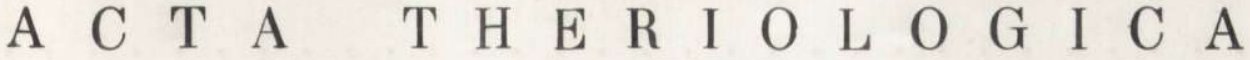

VOL. IX, 6.

BIAEOWIEŻA

30.V.1964

Zofia G E B C Z Y Ń S K A

\section{Morphological Changes Occuring in Laboratory Microtus agrestis with Age}

\author{
Moriologiczna zmienność wiekowa Microtus agrestis \\ w warunkach laboratoryjnych
}

[With 6 Tables, 2 Pls. \& 4 Figs.]

\section{INTRODUCTION}

The problem of morphological changes in mammals has interested many investigators. Seasonal changes in the skulls of the Insectivora have been worked out by Dehnel (1949, 1950), Pucek (1955a, b), Serafiński (1955), and Schubarth (1958), while Prychodko (1951), W a silewski $(1952,1956 a$, b), B a uer (1953), and Adamczewska (1954) dealt with the morphological changes in particular rodents species. These studies were based on the material of wild animals. The growth of some measurements of body and skull in laboratory Microtus arvalis (P a $11 \mathrm{a} \mathrm{s}, 1778$ ) was studied by $\mathrm{Fran} \mathrm{k}$ and $\mathrm{Z} \mathrm{immermann}$ (1957). They arrived at the conclusion that since there is so great variation in the measurements of individual specimens, they cannot make a basis for the determination of age. The same is true of wild populations. Working at the biology and morphology of Pity-

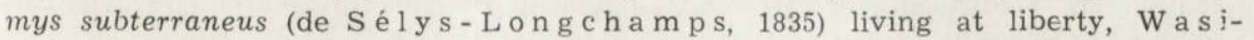
lewski (1960) compared some data with the corresponding values for the laboratory specimens of this species.

As attempts have recently been made to adapt $M$. agrestis to laboratory conditions, it also becomes needful to study the effect of these conditions upon its morphology.

The objective of the present paper is to describe the changes occurring with age in the measurements of the body and the measurements and appearance of the skull of Microtus agrestis ( $\mathrm{Linn}$ a e us, 1761) kept under laboratory conditions. In addition, the development and measurements of $M$. agrestis in captivity will be compared with the data obtained by W a sile wski (1956a) from the wild population of the Białowieża National Park. 


\section{MATERIAL AND METHOD}

The material presented was derived from the laboratory of the Mammals Research Institute, Polish Academy of Sciences, Białowieża. The animals designed for breeding had been caught in the Białowieża National Park since 1955. The laboratory was situated in a provisional frame-house till the spring of 1960 and then moved to special rooms, where lighting and temperature were maintained at a proper level (B uchalczyk, 1961). The voles were kept in pairs or groups consisting of parents and their progeny in cages made of galvanized iron and wire net.

The basic food of $M$. agrestis was grass in summer, hay, beetroots, and carrots in winter. The specimens in bad condition were offered germinating oats, oat flakes with crushed yeast, and, in the case of nursing females, vitamin E.

The material for study was preserved in alcohol. The age of specimens was determined on the basis of records in their inquiry cards. The measurements of body, i.e. the lengths of head and body, tail, foot, and ear, were taken from labels, with which each specimen was provided.

Measurements of the skull, namely, the condylobasal length, basal length, depth of brain-case (measured from the basisphenoid), height of skull (measured through the auditory bulla), occipital breadth, interorbital constriction, and zygomatic breadth, were taken with my own hands, using a vernier caliper for readings to an

Table 1.

Analysis of the total of field voles examined in respect of age.

\begin{tabular}{|c|c|c|c|c|c|c|c|}
\hline \multirow{2}{*}{ Sex } & \multicolumn{5}{|c|}{ Age in months } & \multirow{2}{*}{$\mathrm{n}$} \\
\cline { 2 - 8 } & $1-6$ & $7-12$ & $13-18$ & $19-24$ & $25-29$ & $31-39$ & \\
\hline 09 & 23 & 29 & 28 & 30 & 13 & 7 & 130 \\
$0^{7} 0^{\circ}$ & 37 & 31 & 32 & 27 & 16 & 7 & 150 \\
$\mathrm{n}$ & 60 & 60 & 60 & 57 & 29 & 14 & 280 \\
\hline
\end{tabular}

accuracy of $0.1 \mathrm{~mm}$. The body weight was not taken into consideration, because under laboratory conditions this value is particularly changeable and depending on feeding. The significance of differences between particular measurements was calculated by means of $\mathrm{S} t \mathrm{u}$ de $\mathrm{n}$ t's test.

A total of 280 specimens, 130 females and 150 males, were examined. Their ages ranged from 1 to 39 months and were reckoned from the date of birth (Table 1). Most animals, including all the oldest specimens, died natural deaths.

No specimens over 14 months of age were, as a rule, met with in the wild population of $M$. agrestis from Białowieża. The theoretical maximum life-span of the field vole has been established to be 18 months (W a silew s k i, 1956a). According to $\mathrm{W}$ a silewski animals aged up to 6 months constitute the most numerous group, while the older specimens, 12-14 months old, form a small proportion of the population. In the laboratory, however, there is also a large proportion of still older animals such as are never found in natural populations (Table 1). In $\mathrm{M}$ o h r's opinion (1954), the life-span of microtines kept in the laboratory is up to 2-3 years. 


\section{CHANGES IN MEASUREMENTS OF BODY}

There is an intense increase in the length of body up to the 9th month of life. The mean length is $95.66 \mathrm{~mm}$ in the first month and 124.22 in the 9 th. Then the rate of growth decreases remarkably and is maintained at nearly the same level up to the 20th month of life (Fig. 1). At that time the mean length of body is $121.75 \mathrm{~mm}$. Beyond this limit, up to the 39tir month, there are no statistically significant differences between particular age groups.
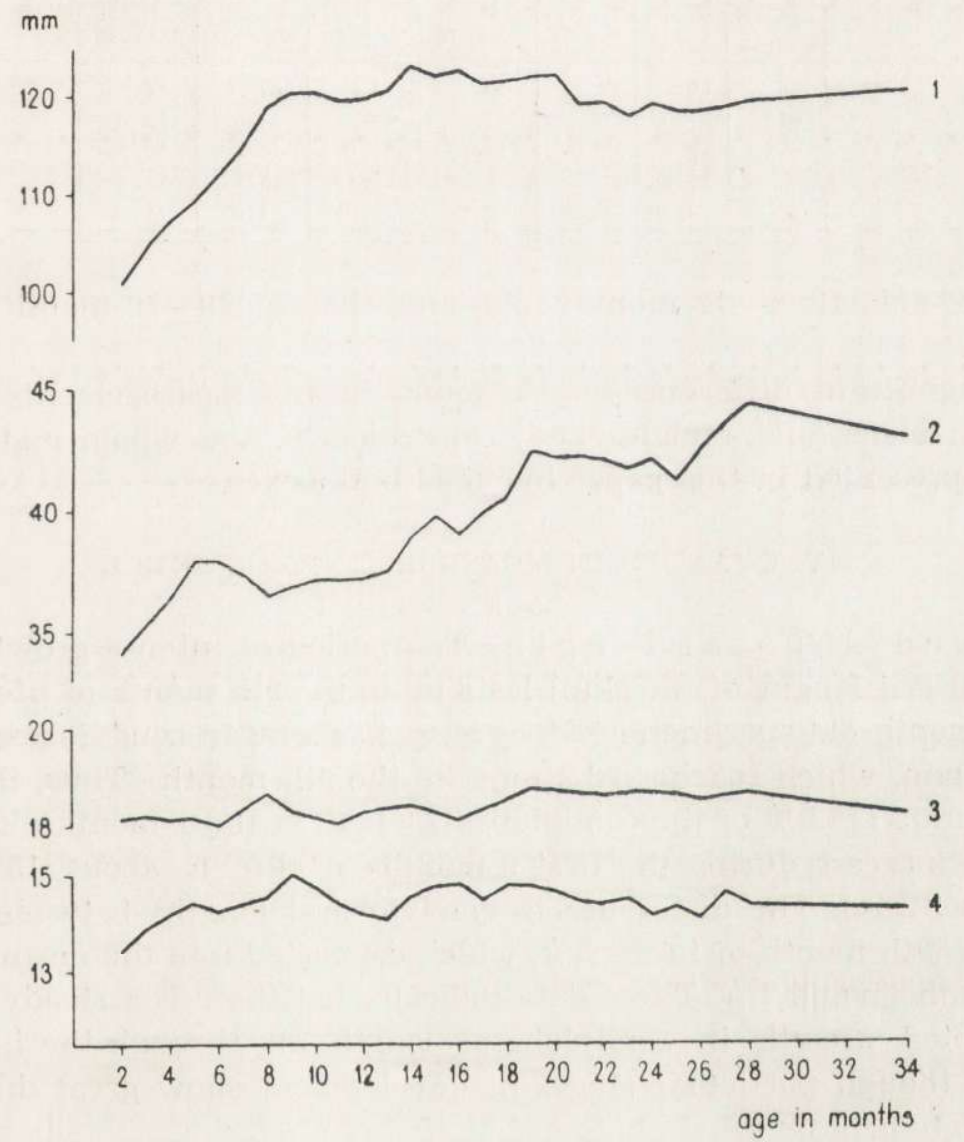

Fig. 1. Growth in body measurements in $M$. agrestis from the laboratory (weighted means of absolute values).

1 - Head and body, 2 - Tail, 3 - Hind foot, 4 - Height of ear.

The length of tail increases all through the life of the animal (Fig. 1), but it should be emphasized that the range of these lengths is very large in all age groups (Table 2). 
The length of hind foot shows no statistically significant differences between $1-6$ month old animals (mean length $-18.15 \mathrm{~mm}$ ) and those 29-39 months of age (mean length $-17.92 \mathrm{~mm}$ ) (Fig. 1).

The intense growth in the height of ear continues up to the 5th month, this height being $13.2 \mathrm{~mm}$ in the 1st month and reaching $14.37 \mathrm{~mm}$ in the 5 th month. No statistically significant differences were found between the

Table 2.

Changes in the length of tail with age.

\begin{tabular}{|c|l|l|l|l|l|l|}
\hline $\begin{array}{c}\text { Age 1n } \\
\text { months }\end{array}$ & $1-6$ & $7-12$ & $13-18$ & $19-24$ & $25-29$ & $31-39$ \\
\hline $\mathrm{n}$ & 60 & 57 & 55 & 51 & 27 & 12 \\
$\min$. & 27 & 26 & 27 & 29 & 34.5 & 32.0 \\
$\max$. & 42.0 & 48.0 & 55.0 & 66.0 & 55.0 & 52.5 \\
$\bar{x}$ & 35.95 & 36.92 & 39.46 & 42.12 & 42.79 & 42.5 \\
$\sigma \bar{x}$ & 0.39 & 0.29 & 0.38 & 0.84 & 1.03 & 1.44 \\
\hline
\end{tabular}

group of animals $6-12$ months old and that of $29-39$ month animals (Fig. 1).

No significant differences were found in any measurements of body between males and females and, consequently, the whole material for graphs presented in this paper included both sexes.

\section{CHANGES IN MEASUREMENTS OF SKULL}

1. Condylobasal le ngth. The period of intense growth in the condylobasal lenght of the skull lasts up to the 9th month of life (Fig. 2). The 1-month-old specimen of $M$. agrestis has a mean condylobasal length of $24.5 \mathrm{~mm}$, which reaches $28.2 \mathrm{~mm}$ in the 9th month. Thus, the latter value forms $114.9 \%$ of the condylobasal length of the 1-month-old animal, and the increase during the first 9 months of life is about $15 \%$ (about $1.9 \%$ monthly). The difference in condylobasal lengths between the 9 th and the 39 th month of life is $3 \%$, which converted into the mean increase per month gives $0.1 \%$. These data indicate that there is a steady and uninterrupted growth in condylobasal length all through the life of the animal, though particular stages of development show great differences in the rate of growth.

In the material under study there were 2 specimens, 17 and 24 months of age, whose skull measurements corresponded to those in specimens 4-6 months old. These differences may have been brought about by unfavourable conditions at an early stage of development (S mirnov, after $\mathrm{S} \mathrm{chwarz}$, 1963). There are also some specimens, in which the skulls are considerably longer than in the remaining voles, e.g. 2 specimens 9 and 10 months old having condylobasal lengths of $29.5 \mathrm{~mm}$ and 
3 specimens aged 19-21 months with condylobasal lengths ranging between 30.2 and $30.5 \mathrm{~mm}$. No skulls with so great condylobasal lengths were found in any other age group. Such extreme values have not been taken into account in the calculation of mean values for particular age groups (Table 3 ).

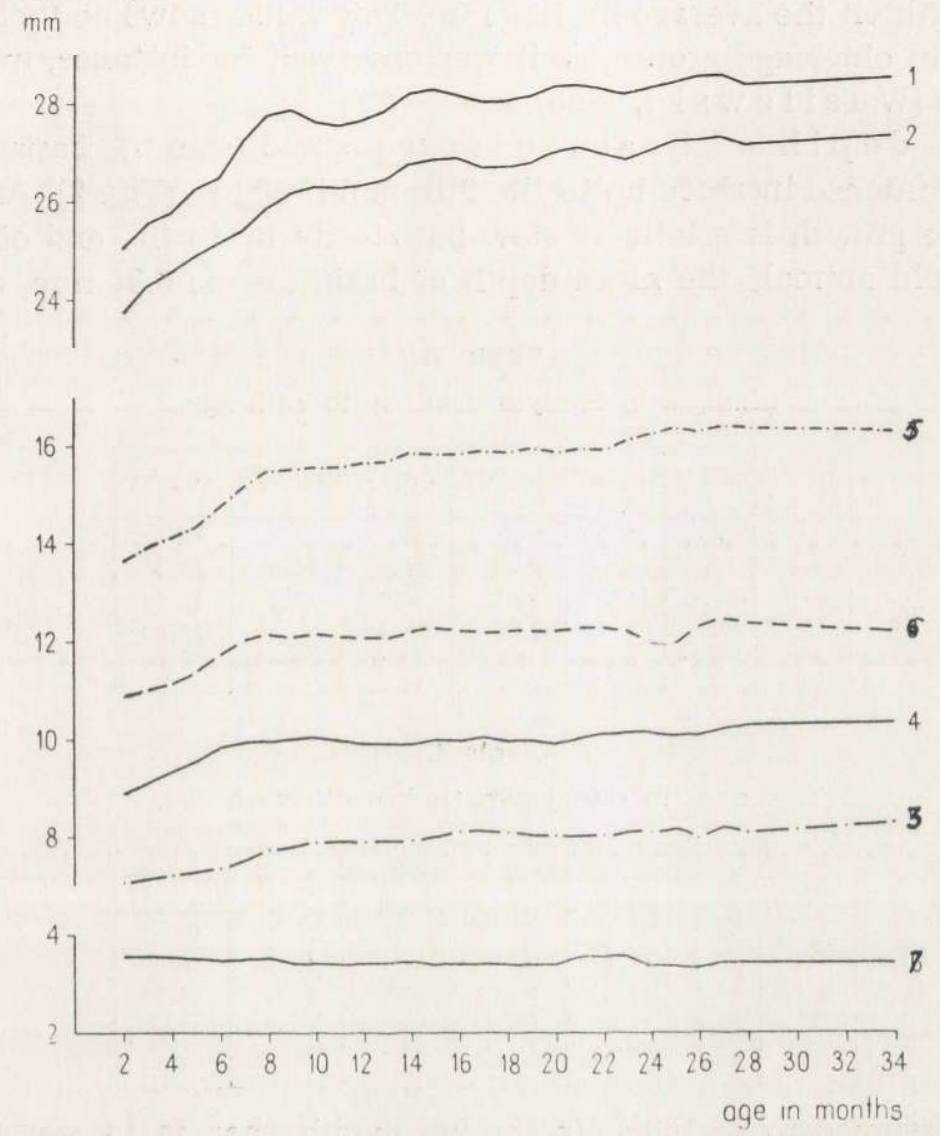

Fig. 2. Growth in skull measurements in $M$. agrestis from the laboratory (weighted means of absolute values).

1 - Condylobasal length, 2-Basal length, 3- Depth of brain-case, 4- Height of skull, 5 - Zygomatic breadth, 6 - Occipital breadth, 7 - Interorbital constriction.

No statistically significant differences were observed in the growtin rate of condylobasal length and all the other measurements of skull between males and females, similarly to what had already been found in the wild population (W a si l e w sk i, 1956a).

2. Basal le $\mathrm{ngth}$. The growth of this length agrees with that of the condylobasal length. The curves of growth for both these measurements are parallel in all the age groups (Fig. 2). The period of intense 
growth lasts up to the 9th month, after which the rate of growth diminishes considerably (Fig. 4). The length of skull base increases also between the 10th and the 39th month, but to a far lower degree than in the preceding period.

In all age groups the length of skull base is smaller than the condylobasal length on the average by $1.25 \mathrm{~mm}$. This value shows no tendency to decrease in older age groups, as it was observed, for instance, in $P$. subterraneus (W a sile ws ki, 1960).

3. The depth of brain-case (measured from the basisphenoid) shows an intense increase up to the 9 th month of life (Fig. 2). After this period the growth is relatively slow but steady up to the end of life. In 1-month-old animals the mean depth of brain-case is $6.94 \mathrm{~mm}$, and this

Table 3.

Changes in condylobasal length with age.

\begin{tabular}{|c|l|l|l|l|l|l|}
\hline $\begin{array}{c}\text { Age 1n } \\
\text { months }\end{array}$ & $1-6$ & $7-12$ & $13-18$ & $19-24$ & $25-29$ & $31-39$ \\
\hline $\mathrm{n}$ & 60 & 62 & 58 & 57 & 29 & 14 \\
$\min$. & 23.1 & 24.3 & 26.3 & 26.6 & 27.1 & 27.9 \\
$\max$. & 28.1 & 29.0 & 29.8 & 30.0 & 29.9 & 30.0 \\
$\overline{\mathrm{x}}$ & 25.54 & 27.3 & 28.13 & 28.31 & 28.48 & 28.78 \\
$\sigma \overline{\mathrm{x}}$ & 0.19 & 0.68 & 0.12 & 0.10 & 0.13 & 1.03 \\
\hline
\end{tabular}

Table 4.

Changes in the zygomatic breadth with age.

\begin{tabular}{|c|l|l|l|l|l|l|}
\hline $\begin{array}{c}\text { Age 1n } \\
\text { months }\end{array}$ & $1-6$ & $7-12$ & $13-18$ & $19-24$ & $25-29$ & $31-39$ \\
\hline $\mathrm{n}$ & 52 & 53 & 53 & 50 & 24 & 13 \\
$\min$. & 12.5 & 14.1 & 14.4 & 14.7 & 15.1 & 14.9 \\
max. & 16.0 & 17.3 & 16.8 & 17.5 & 17.5 & 17.7 \\
$\overline{\mathrm{x}}$ & 13.97 & 15.54 & 15.86 & 15.93 & 16.26 & 16.22 \\
$\sigma \overline{\mathrm{x}}$ & 0.11 & 0.13 & 0.07 & 0.11 & 0.15 & 0.23 \\
\hline
\end{tabular}

value is assumed to be $100 \%$. In the 9 th month, that is to say the last month of intense growth, the depth is $7.95 \mathrm{~mm}(114.3 \%)$, whereas in the 18 th month its mean value amounts to $8.08 \mathrm{~mm}(117.7 \%)$. Similarly to the condylobasal length and the basal length the depth of brain-case measured from the basisphenoid grows rapidly in $M$. agrestis in the first months of life, next much more slowly but steadily to the end of life (Fig. 4).

4. The height of skull (measured through the auditory bulla) increases most intensely in the first 9-10 months. The mean depth being $8.92 \mathrm{~mm}(100 \%)$ in the 1 st month, it reaches $9.98 \mathrm{~mm}(111.9 \%)$ in the $10 \mathrm{th}$ month, $10.11 \mathrm{~mm}(113.3 \%)$ in the 18 th, and $10.3 \mathrm{~mm}(115.4 \%)$ in the period from the 31 st to the 39 th month (Fig. 4). 


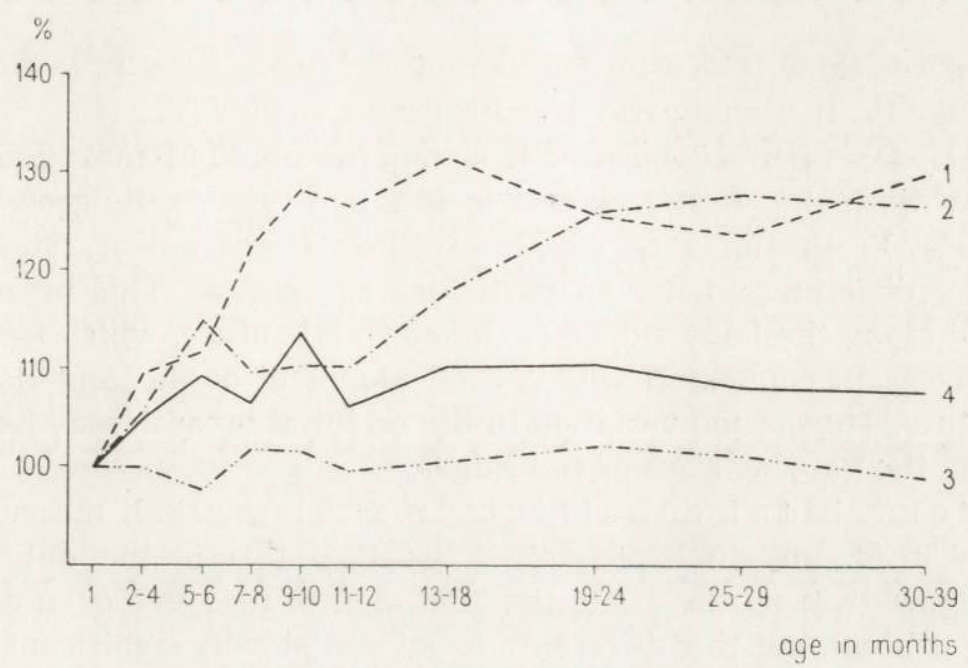

Fig. 3. Rate of growth in body measurements in M. agrestis from the laboratory (expressed in percentages of the value for the first month of life).

1 - Head and body, 2 - Tail, 3 - Hind foot, 4 - Height of ear.

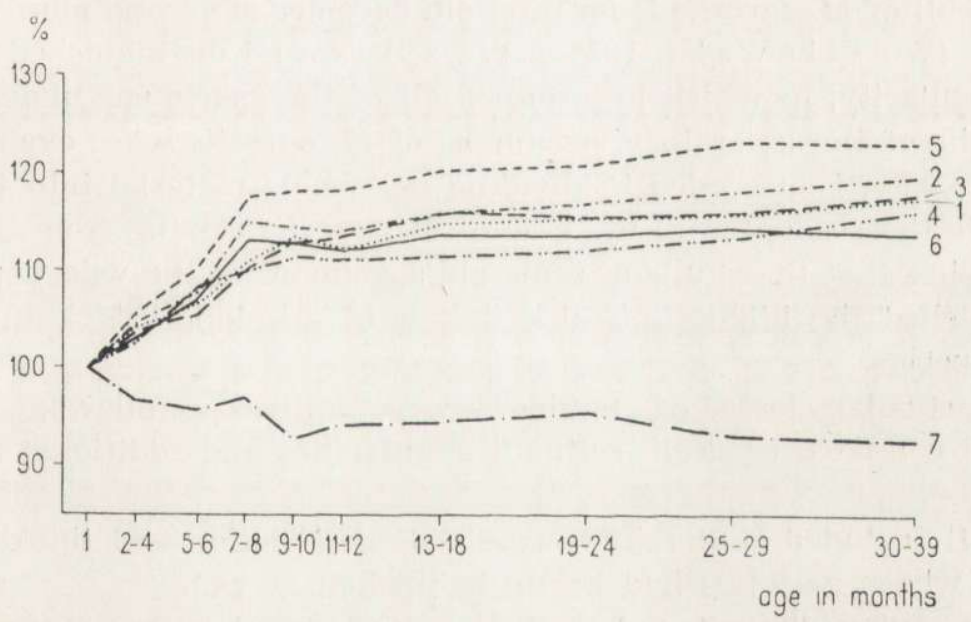

Fig. 4. Rate of growth in skull measurements in $M$. agrestis from the laboratory (expressed in percentages of the value for the first month of life).

1 - Condylobasal length, 2 - Basal length, 3 - Depth of brain-case, 4 - Height of skull, 5 - Zygomatic breadth, 6 - Occipital breadth, 7 - Interorbital constriction.

5. Zy g o matic breadth. The mean growth in zygomatic breadth is offered in Fig. 3, and its extreme values were used to make up Table 4. In the 1st month of life the zygomatic breadth averages $13.2 \mathrm{~mm}$; in the last, i.e. the ninth, month of intense growth it is $15.55 \mathrm{~mm}(117.9 \%)$, and in the 18 th month it reaches $16.15 \mathrm{~mm}(122.5 \%)$. In the oldest age group (31st-39th month) the mean zygomatic breadth is $16.22 \mathrm{~mm}(123.1 \%)$. 
These figures show that after the period of intense growth, lasting up to the 9 th month, the zygomatic breadth grows on slowly.

6. The occipital breadth amounts to $12.01 \mathrm{~mm}$ in the 9 th month, while in the first month it is $10.7 \mathrm{~mm}$ (Fig. 2), its growth being thus $13.4 \%$. From the 10 th month onwards there are no statistically significant differences between particular age groups. This breadth was measured along the bony ridges of the occipital suture, which increase in size with age in connexion with the development of the cephalocervical musculature. Thus, some variation in the occipital breadth may have been caused by the varying sizes of the ridges.

7. Interorbital constriction. Of all the skull measurements examined in $M$. agrestis kept in the laboratory this is the only one to show no growth from the 1st to the 39 th month. Its value even decreases by about $0.2 \mathrm{~mm}$, but this difference is not statistically significant (Fig. 2).

\section{OLD-AGE CHANGES IN THE SKULL}

The skull of $M$. agrestis from the field becomes more and more angular with age (W a si l e w sk i, 1956a). W a s i l e w sk i distinguished 4 classes of angularity, in which he grouped all of the specimens under study. The skulls of the laboratory specimens of $M$. agrestis were examined in the same way. I succeeded in dividing my whole material into 4 classes similar to those adopted in the case of $M$. agrestis coming from the field. This implies that the skulls of some old specimens of the wild population have reached the highest possible degree of development of angularity in this species.

The particular classes of angularity were defined as follows:

Class I consisted of skulls without angularities and additional thickenings.

Class II included skulls showing visible ossification and thickening of sutures, whose parietals had begun to thicken as well.

Skulls having distinct and well-developed angularities on the nuchal crest and strongly thickened parietals with conspicuously bulging places of the attachment of muscles belonged to class III.

The remaining, very distinctly angular skulls were placed in class IV.

It has been found that there are some differences in the rate of formation of angularity between the laboratory population of the field vole and the wild one (Table 5). In the corresponding age groups this difference is expressed by a greater proportional share of the skulls of laboratory specimens with pronounced angularities. In the age groups represented only by laboratory specimens, the skulls with very pronounced angularities prevail decidedly. 
Tuberous bulges on the external side of the mandible are the phenomenon observed only in the laboratory specimens of M. agrestis. They are most numerous in the middle portion of the mandibular body, sometimes in the lower portion of the ramus. Similar formations occur occasionally on the maxilla.

These tuberous growths are never found in specimens less than 8 months old. In animals more than 8 months of age, $20-25 \%$ of specimens have these kinds of deformation. They sometimes cause a distortion of the tooth row as well. B a she nina (1953) thought that the origin of such growths is effected by the action of actinomycosis.

Table 5.

Rate of formation of angularity in the skulls of $M$. agrestis from the field (calculated from the data given by W a s i le w sk i, 1956) and from the laboratory.

\begin{tabular}{|c|c|c|c|c|c|c|c|c|}
\hline \multirow[b]{2}{*}{ Age in months } & \multicolumn{4}{|c|}{ F I B L D } & \multicolumn{4}{|c|}{ LA BORATOR $Y$} \\
\hline & 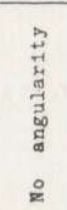 & $\begin{array}{l}4 \\
\vdots \\
\circ\end{array}$ & $\begin{array}{l}\text { J } \\
\vdots \\
\vdots \\
\Xi \\
\Xi \\
\vdots \\
0 \\
\text { L. }\end{array}$ & 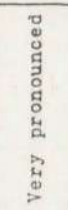 & 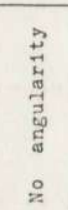 & $\begin{array}{l}\text { मे } \\
\text { ㅇ. }\end{array}$ & 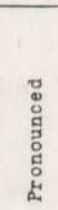 & 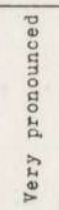 \\
\hline $1-6$ & 91.5 & 8.5 & - & - & 93.4 & 6.6 & - & - \\
\hline $7-12$ & 41.5 & 43.4 & 15.1 & - & 9.8 & 27.9 & 52.5 & 9.8 \\
\hline $13-18$ & - & 17.2 & 55.2 & 27.6 & - & 15.3 & 49.1 & 35.6 \\
\hline $19-24$ & - & - & - & - & 3.4 & 3.5 & 43.1 & 50.0 \\
\hline $25-39$ & - & - & - & - & - & 7.1 & 28.6 & 64.3 \\
\hline
\end{tabular}

The incisors of laboratory animals often show damages (fractures, crumbling) caused probably by specific conditions under which these animals are kept (cages with metal wire nets). This kind of damages of the dentition brings about a growth of the opposite incisor by interrupting the normal process of wear of the tooth (Plate I, II). M o h r (1950) and A $1 \mathrm{t} n$ e r (1961) described similar cases of tooth deformations in $M$. arvalis and Freye (1959) in Castor fiber albicus M a t s ch i e, 1907.

\section{DISCUSSION}

On the basis of the measurements of body and skull and their growth with age in $M$. agrestis kept under laboratory conditions it may be stated that the period of intense growth lasts in this species up to the 9th or 10th month of life (Figs. 3 and 4). This is true of all the measurements of the field vole except the height of ear, which grows only till the 5 th month, and the length of foot and the interorbital constriction, which do not change significantly at all between the 1st and the 39 th month of life, 
After the first 9-10 month period the occipital breadth and both the depths of brain-case do not increase any more, and the small differences found between the age groups are statistically insignificant. In specimens 12-18 months old a growth is still found in the length of head and body and tail as well as in the condylobasal length, basal length, and zygomatic breadth. The last three measurements increase up to the end of the life-span.

The non-uniformity of the rate of growth of the skull in the course of life causes a change in its general appearance and proportions. In the case of $M$. agrestis kept in the laboratory a skull flattening and fairly pronounced bulging and thickening of the zygomatic arches are observed in the advanced age groups (Fig. 4). The flattening of the skull is only natural in the light of the fact that the skull base grows steadily with age, whereas the depth of the brain-case augments far more slowly.

Table 6.

Comparison of some measurements of $M$. agrestis from the laboratory and from the field (calculated from the data given by Wa silew ski, 1956).

\begin{tabular}{|c|c|c|c|c|c|c|c|c|c|}
\hline \multirow[b]{3}{*}{ Age in months } & \multirow{2}{*}{\multicolumn{6}{|c|}{$I A B O R A T O R Y$}} & \multicolumn{3}{|c|}{ 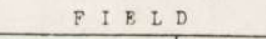 } \\
\hline & & & & & & & \multicolumn{2}{|c|}{ young } & $\begin{array}{l}\text { old } \\
\text { adult }\end{array}$ \\
\hline & $\begin{array}{l}0 \\
1 \\
-\end{array}$ & $\begin{array}{l}\sim \\
1 \\
r\end{array}$ & $\begin{array}{l}\stackrel{\infty}{1} \\
\vdots \\
m\end{array}$ & $\begin{array}{l}\text { N } \\
1 \\
a \\
\stackrel{1}{1}\end{array}$ & $\begin{array}{l}2 \\
\sim \\
1 \\
\approx\end{array}$ & $\begin{array}{l}\text { ì } \\
\vdots \\
\dot{n}\end{array}$ & $\begin{array}{l}x \\
1 \\
>\end{array}$ & $\begin{array}{l}z \\
1 \\
\stackrel{x}{x}\end{array}$ & $\begin{array}{l}\vec{x} \\
1 \\
>\end{array}$ \\
\hline Head and body & 106.5 & 120.7 & 125.7 & 120.4 & 118.2 & 124.3 & 99.1 & 98.9 & 116.5 \\
\hline Cb.-lenght & 25.5 & 27.5 & 28.1 & 28.3 & 28.4 & 28.7 & 24.2 & 25.7 & 26.9 \\
\hline Depth of bra1n-case & 7.2 & 7.79 & 8.05 & 8.02 & 8.06 & 8.33 & 7.44 & 7.36 & 7.69 \\
\hline 2ygomat $1 \mathrm{c}$ breadth & 13.6 & 15.5 & 15.8 & 15.9 & 16.2 & 16.2 & 13.6 & 14.3 & 15.1 \\
\hline
\end{tabular}

A similar phenomenon has been described in Pitymys subterraneus (W a silewski, 1960) and M. arvalis (B a s h e nina, 1953).

As for the determination of age from morphological characters, it should be emphasized that in the case of laboratory specimens of $M$. agrestis the body measurements cannot constitute a basis for such determination. Only in young age groups the length of body and height of ear may be of some informative importance in this respect. As regards the older age groups, none of the measurements can be used for this purpose. In these groups the growth in measurements is slight and at the same time they show great individual variation. Instead, it is possible to determine the age of a specimen fairly correctly on the basis of such characters of the skull as, for instance, the condylobasal length, the basal length, and the zygomatic breadth. In many cases individual variation of skull measurements may be an actual difficulty. 
On comparing the measurements of body and skull and their rate of growth in a field population of $M$. agrestis (W a s i l e w sk i, 1956a) with those in the laboratory specimens it can be stated that this vole is larger in laboratory conditions than in the field in corresponding age groups. The differences are particularly apparent in the length of body, length of tail, condylobasal length, basal length, zygomatic breadth, and depth of brain-case [except for the first 6 months of life, when the mean for the laboratory voles is smaller by $0.2 \mathrm{~mm}$ than that for the members of the wild population (Table 6)].

The fact that $M$. agrestis kept in the laboratory reaches large measurements and lives longer than under field conditions is undoubtedly brought about by its advantageous food conditions, its being free from predators, etc. The larger measurements and the faster development of angularity indicate also that in the laboratory the animal does not grow in the same manner as in the field. The corresponding age groups from these two different environments practically cannot be compared in the direct manner. The influence exerted by varying physical conditions of these environments upon the growth rate in both laboratory and wild populations is so essential as to become decisive as far as the measurements of body and the measurements and appearance of skull are concerned.

The difference between the influence of the laboratory and that of a natural environment is aiso shown by some laboratory specimens having measurements evidently smaller than the averages for the given age groups. It is so because in some cases the laboratory conditions have a great inhibiting effect on the development and growth of animals. The conditions during early stages of development are particularly effective and essential (S mirnov, after Schwarz, 1963).

\section{SUMMARY}

On an examination of morphological changes in 280 specimens of $M$. agrestis kept in the laboratory for 1 to 7 generations the following conclusions were made:

1. There are no statistically significant differences in the measurements of body and skull between males and females of $M$. agrestis from the laboratory.

2. The period of intense growth in the length of body, condylobasal length, basal length, depth of brain-case, height of skull measured through the auditory bulla, zygomatic breadth, and occipital breadth lasts up to the 9th or 10th month of life Besides, the length of head and body, length of tail, condylobasal length, basal length, and zygomatic breadth grow on till the 18th month. The last three of these measurements grow steadily to the end of the vole's life.

3. The development of angularity of the skull is one of the signs of ageing.

4. The length of body, height of ear (in young are groups), condylobasal length, basal length, and zygomatic breadth can be used to determine the age of the laboratory specimens of $M$. agrestis approximately. 
5. The measurements of body and skull in $M$. agrestis from the laboratory are larger than those in field specimens in the corresponding age groups. The development of angularity in them is faster.

6. Under laboratory conditions, about $20-25 \%$ of specimens more than 8 months old show a development of tuberous growths on their jaws, which very often result in greatly disadvantageous changes in the dentition.

\section{REFERENCES}

1. A d a m c zewska, K., 1959: Untersuchungen über die Variabilität der Gelbhalsmaus, Apodemus flavicollis flavicollis (M e l chior, 1834). Acta theriol., 3, 10: 141-190. Białowieża.

2. Altner, H., 1961: Zahnmissbildungen von Wühlmäusen aus Eulengewöllen. Ornithol. Mitt., 13, 10: 181-182.

3. Bas henina, N. W., 1953: K voprosu ob opredelenij vozrasta obyknovennoj polevki (Microtus arvalis P a 11.). Zool. Żurn., 32, 4: 730-743. Moskva.

4. B a uer, K., 1953: Zur Kenntnis von Microtus oeconomus méhelyi E hi k. Zool. Jb. (Syst.), 82, 1/2: 71-94. Jena.

5. B u chalczyk, A., 1961: Pitymys subterraneus (de Sély s-Long cham ps, 1835) under laboratory conditions. Acta theriol., 4, 14: 282-284. Białowieża.

6. De hne 1, A., 1949: Badania nad rodzajem Sorex L. Ann. Univ. M. Curie-Skłodowska, C, 4, 2: 17-102. Lublin.

7. De hne 1, A., 1950: Badania nad rodzajem Neomys K a u p. Ann. Univ. M. Curie-Skłodowska, C, 5, 1: 1-63. Lublin.

8. Frank, F. \& Zimmermann, K., 1957: Uber die Beziehnungen zwischen Lebensalter und morphologischen Merkmalen bei der Feldmaus, Microtus arvalıs (P a 11.). Zool. Jb. (Syst.), 85, 3: 283-300. Jena.

9. Mohr, E., 1950: Die freilebenden Nagetiere Deutschlands und der Nachbarlän* der. $1-152+$ VI. Jena.

10. Prychodk o, W., 1951: Zur Variabilität der Rötelmaus, Clethrionomys glareolus glareolus in Bayern. Zool. Jb. (Syst.), 80, 5/6: 482-506. Jena.

11. Pucek, Z., 1955 a: Badania nad mechanizmem zmienności czaszki Sorex araneus araneus L. Kosmos A, 4: 317-319. Warszawa.

12. P u cek, Z., 1955 b: Untersuchungen über die Veränderlichkeit des Schädels in? Lebenszyklus von Sorex araneus araneus L. Ann. Univ. M. Curie-Skłodowska, C 9, 4: 163-211. Lublin.

13. S e rafiński, W., 1955: Badania morfologiczne i ekologiczne nad polskimi gatunkami rodzaju Sorex L. (Insectivora, Soricidae). Acta theriol., 1, 3: 27-85. Warszawa.

14. S c hwarz, S. S., 1963: Vnutrividovaja izmenčivost' mlekopitajuščih i metody jejo izučenija. Zool. Żurn., 42, 3: 417-433. Moskva.

15. W a silewski, W., 1952: Morphologische Untersuchungen über Clethrionomys glareolus glareolus S chre b. Ann. Univ. M. Curie-Skłodowska, C, 7, 3: 119211. Lublin.

16. W a silew ski, W., 1956 a: Untersuchungen über die morphologische Veränderlichkeit der Erdmaus (Microtus agrestis Linnaeus). Ann. Univ. M. Curie-Skłodowska, C, 9, 6: 261-305. Lublin. 
17. W a silewski, W., 1956 b: Untersuchungen über die Veränderlichkeit des Microtus oeconomus Pa 11. in Białowieża - National Park. Ann. Univ. M. Curie-Skłodowska, C, 9, 8: 355-386. Lublin.

18. W a si lew s k i, W., 1960: Angaben zur Biologie und Morphologie der Kurzohrmaus, Pitymys subterraneus (de S ély s-Long champs, 1835). Acta theriol., 4, 12: 185-247. Białowieża.

Polish Academy of Sciences, Mammals Research Institute, Białowieża, woj. Białystok.

\section{STRESZCZENIE}

Po przebadaniu wiekowej zmienności morfologicznej 280 osobników (Tabela 1) Microtus agrestis (L in na e us, 1761) trzymanych w warunkach hodowli laboratoryjnej od 1 do 7 pokoleń, można wyciągnąc następujące wnioski:

1. U M. agrestis z hodowli nie występują między samcami i samicami różnice istotne statystycznie w wymiarach ciała i czaszki.

2. Okres intensywnego wzrostu wymiarów: długości ciała, długości Cb., dlugości podstawy czaszki, wysokości puszki mózgowej (mierzona od basi sphaenoidale), wy. sokości puszki mózgowej (mierzonej przez bullae tympanici), szerokości jarzmowej, szerokości potylicy trwa do 9-10 miesiąca życia zwierzęcia. Do 18 miesiąca rosną jeszcze: długość ciała, długość ogona, długość Cb., długość podstawy czaszki, szerokość jarzmowa. Trzy ostatnie z wymienionych pomiarów rosną do końca życia zwierzęcia (Ryc. 1, 2).

3. Jednym z objawów starzenia się jest rozwój kanciastości na czaszce (Tabela 5).

4. Wymiary długości ciała, oraz długości ucha (w młodszych grupach wiekowych), a także długości Cb., długości podstawy czaszki i szerokości jarzmowej - mogą służyć do orientacyjnego oznaczania wieku zwierząt w hodowli.

5. Wymiary ciała i czaszki $M$. agrestis z hodowli sa wyższe w odpowiednich grupach wiekowych, niż u osobników z terenu (Tabela 5). Swiadczyć to może o tym, że zwierzęta równowiekowe z terenu i z hodowli nie są ,równowartościowe” pod względem morfologicznym, a zatem ich bezpośrednie porównywanie może mieć jedynie charakter orientacyjny.

6. W warunkach hodowlanych u zwierząt starszych niż 8 miesięcy, u około 20 -25\% osobników następuje rozwój guzowatych narośli, co często pociąga za sobą niekorzystne zmiany w uzębieniu. Tego rodzaju guzowate naros̉la tworzą się najczęściej na żuchwie (Tablice I-II).

\section{EXPLANATION OF PLATES}

Plate I.

Development of angularity in skulls of $M$. agrestis.

Plate II.

Phot. 5. Abnormally developed inscisors of maxilla.

Phot. 6. Broken and completely worn out upper inscisors.

Phot. 7. Tuberosities on a mandible.

Phot. 8. Deformation of maxillary tooth row. 


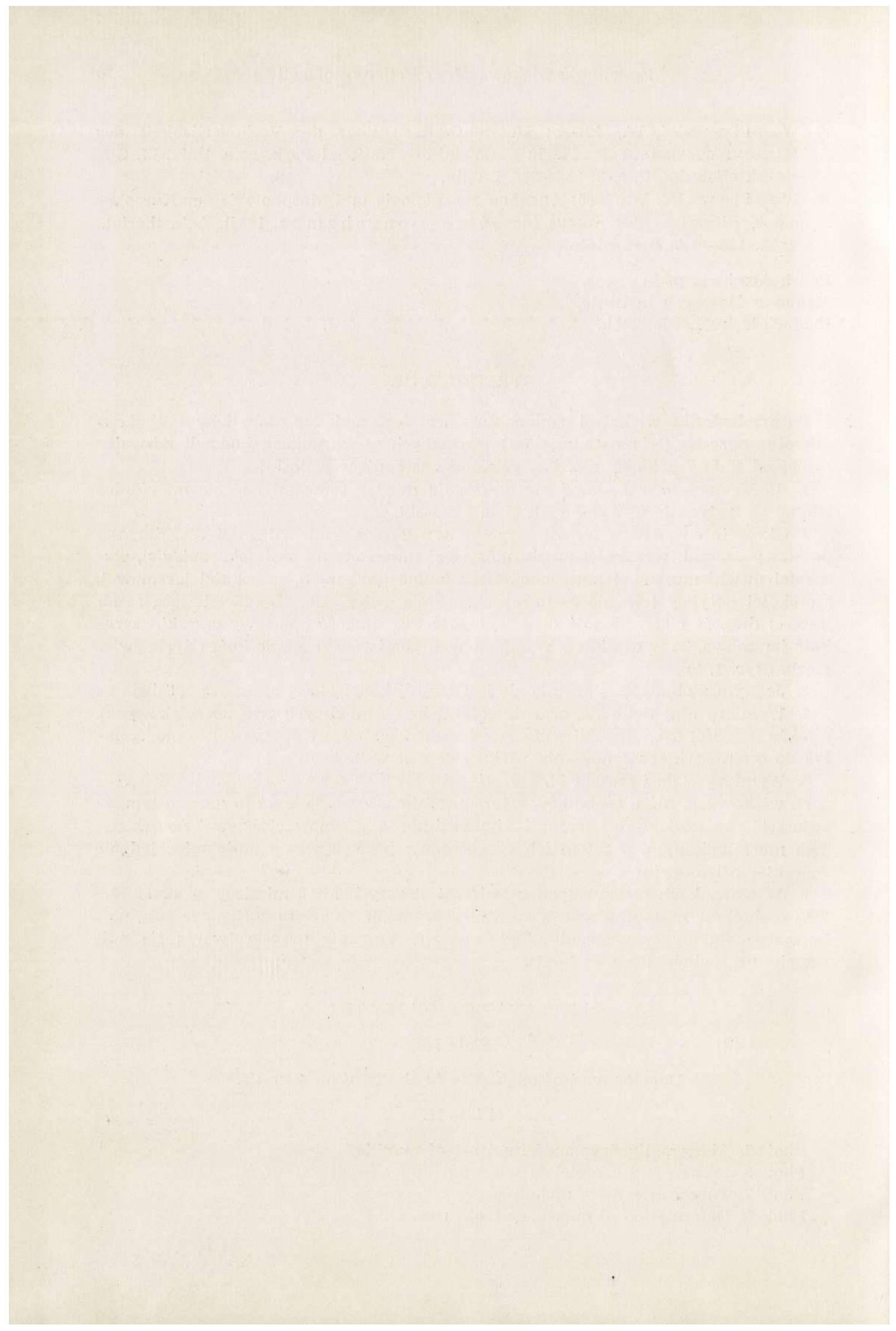



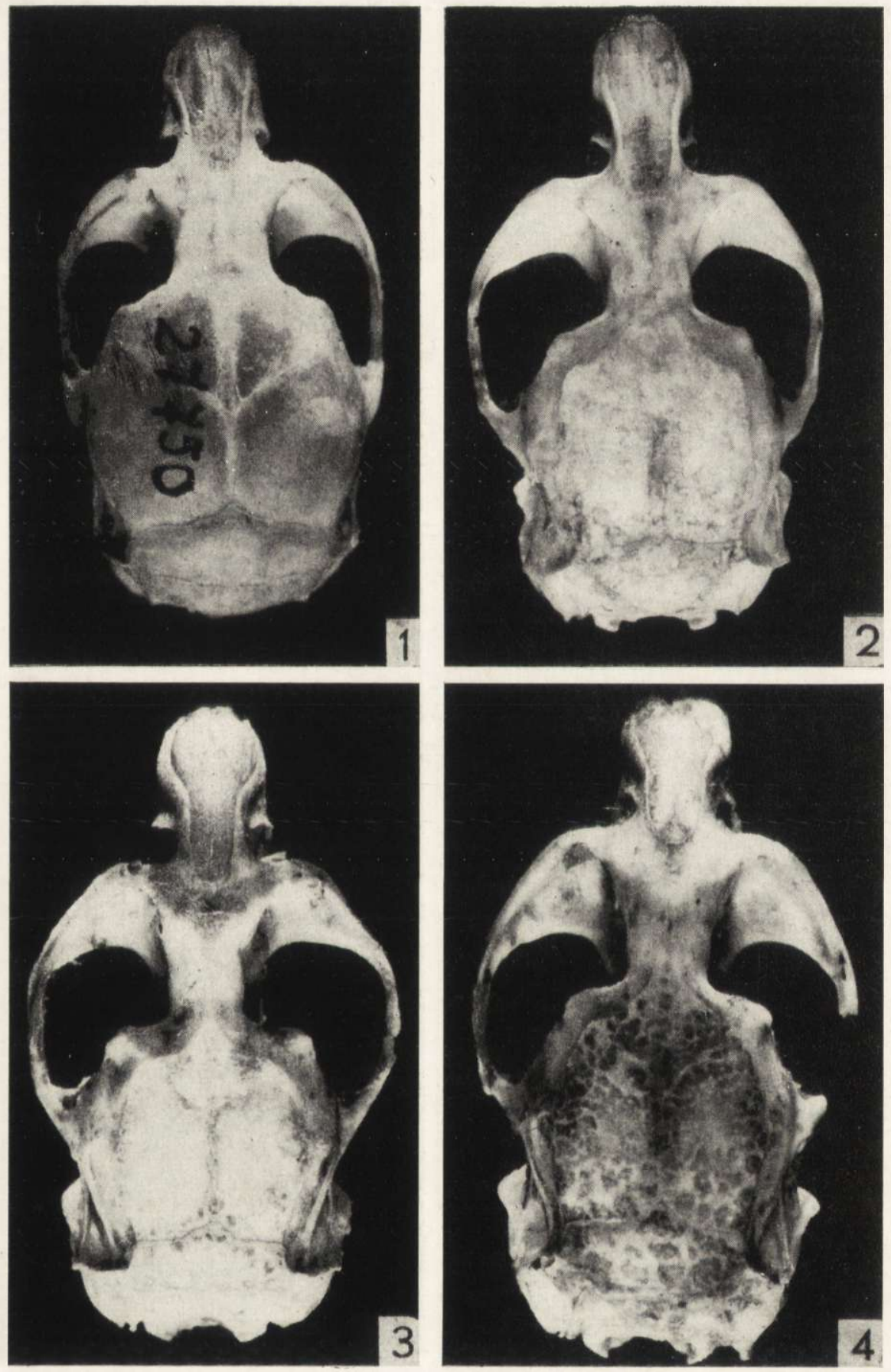

Z. Gębczyńska

J. Raczyński phot. 
ACTA THERIOLOGICA Vol. IX, 6.
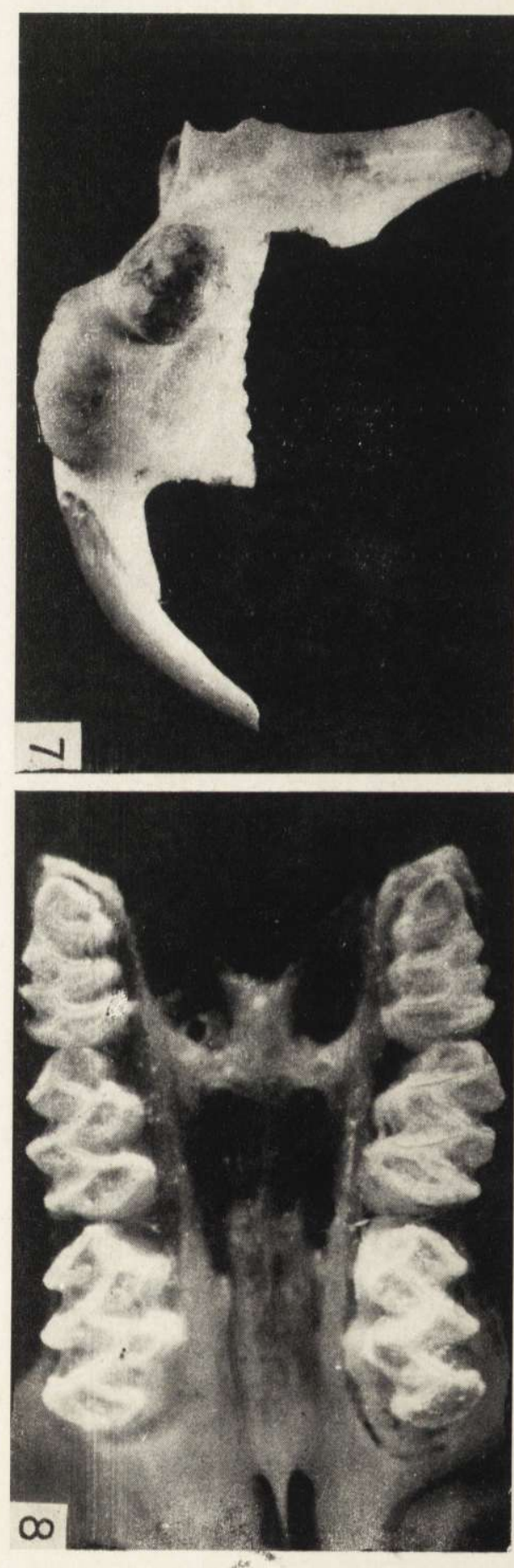

Z. Gębczyńska
Plate II.
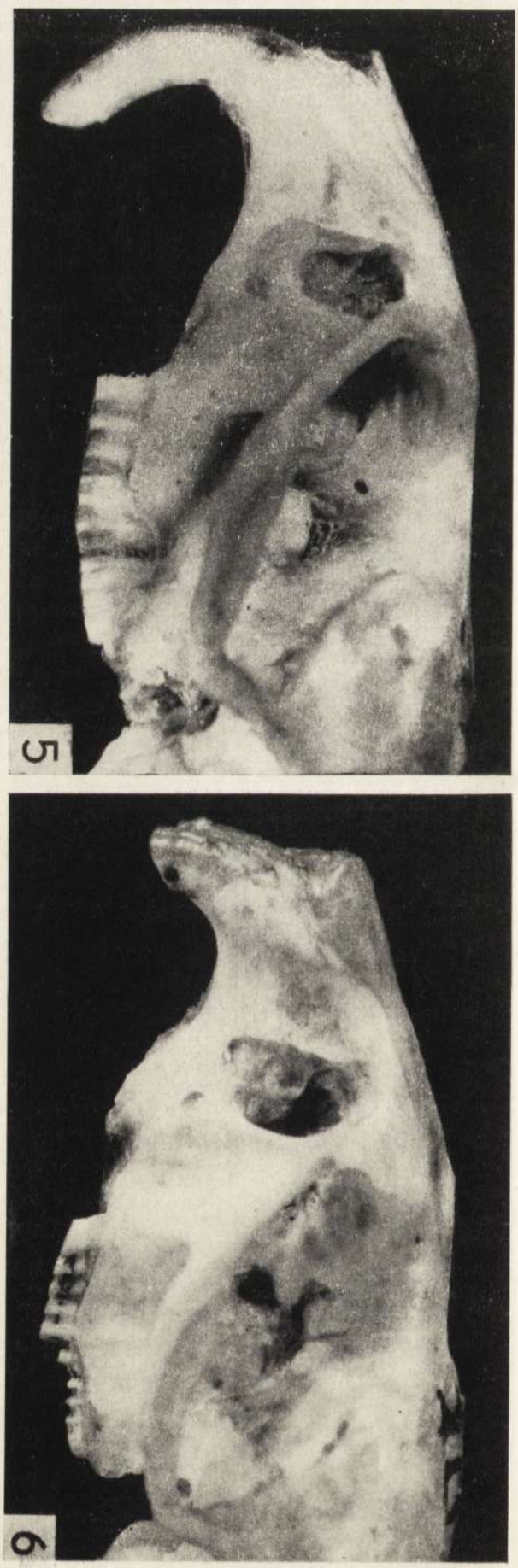

J. Raczyński phot. 